\title{
Lower Jaw and Orolabial Analysis in Adult Bangladeshi Buddhist Chakma Females
}

Asma Mostafa ${ }^{1^{*}}$

Laila Anjuman Banu²

Azmeri Sultana ${ }^{3}$

'Department of Anatomy

Chattagram Maa-O-Shishu Hospital Medical

College, Chittagong, Bangladesh.

${ }^{2}$ Department of Anatomy

Bangabandhu Sheikh Mujib Medical University, Shahbag, Dhaka, Bangladesh.

${ }^{3}$ Department of Paediatrics

Institute of Child Health and Shishu Sashthya

Foundation Hospital

Mirpur, Dhaka, Bangladesh.

\section{*Correspondence to:}

\section{Dr. Asma Mostafa}

Assistant Professor, Department of Anatomy

Chattagram Maa-O-Shishu Hospital

Medical College.

Chittagong, Bangladesh.

E-mail: asmamostafaisrat@yahoo.com

Mobile : 01911109617

\begin{abstract}
Background: It is well accepted that a single standard of craniofacial norms is not appropriate for application to diverse racial and ethnic groups, even for different sex and ages in same ethnic group. So it is necessary to develop craniofacial norms for different groups based on above factors. The present study was designed to establish the baseline measurements of the lower jaw and orolabial anthropometrical parameters and indices, and also to evaluate the differences (if any) on age related morphological variations of adult Bangladeshi Buddhist Chakma females. Methods: The study was descriptive, observational and cross-sectional in nature with some analytical components. The study group consisted of a convenient sample of 100 adult Bangladeshi Buddhist Chakma females; categorized into two groups - 25 to 35 years $(n=70)$ and 35 to 45 years $(n=30)$. Variables were measured using physical and photographic procedures. Indices were calculated from those variables. An independent " $\mathrm{t}$ " test was performed to evaluate if there was any significant difference in measurements between the two age groups setting a $\mathrm{p}$ value of $\leq 0.05$ as statistically significant. Results: All measurements show statistically non significant difference between two age groups except philtrum length $(p=0.02)$ and upper vermilion height to philtrum length index $(\mathrm{p}=0.03)$. Conclusions: The result of this study can be useful for anatomists and anthropologists to serve as a basic framework for estimating the standard of lower jaw and orolabial dimensions of this population and also to compare the craniofacial dimensions of other ethnic groups of Bangladesh with this ethnic group.
\end{abstract}

Key words: Anthropometry; Orolabial anthropometry; Bangladeshi chakma females.

\section{INTRODUCTION}

Variation in different morphological characters is one of the most important phenomena occurring in human and is attributed to many factors such as mutation and natural selection. The dimensions of the human body are affected by ecological, biological, geographical, racial, gender and age factors. So, anthropometric measurements as a mean of studying variations of human population should be based on above factors. This necessity rests on the fact that there will be greater validity if an individual is compared to referent data matched for their specific ethnic group, sex and age.

Lower jaw and orolabial anthropometry can be useful for quantitative evaluation of dysmorphic syndromes. Morphological features of various syndromes are usually described on the basis of qualitative method, which is subjective and clinical impression can be misleading ${ }^{1}$. Even among specialists, there is often disagreement with respect to minor anomalies ${ }^{2}$. Such problems will overcome if craniofacial measurements taken from a patient compared with the normal values obtained from a reference population.

Lower jaw and orolabial anthropometry can also be used in plastic and reconstructive surgery, oral surgery and dentistry. To treat any congenital or posttraumatic disfigurements in members of different ethnic groups successfully, surgeons require access to the normative measurements of that group ${ }^{3}$ for precise determination of the degree of deviations from the normal and to assess any improvement achieved through treatment ${ }^{4}$. 
It is reported by various researchers that facial dimensions continue to modify during adulthood, even after complete biological maturation. ${ }^{5}$. As no published data are available at present, it is necessary to standardize the normative value of lower jaw and orolabial measurements for this ethnic group. Therefore, the present study was designed to establish the baseline measurements of the lower jaw and orolabial anthropometrical parameters and indices, and also to evaluate the differences (if any) on age related morphological variations in lower jaw and orolabial region of the adult Bangladeshi Buddhist Chakma females that may be necessary for future reference in these regard.

\section{MATERIALS AND METHODS}

\section{Study design}

The study was descriptive, observational and cross-sectional in nature with some analytical components.

\section{Study settings}

The study group consisted of a convenient sample of 100 adult $B$ angladeshi Buddhist Chakma females; categorized into two groups - 25 to 35 years $(n=70)$ and 35 to 45 years $(n=30)$. Subjects excluded from the study were those - mixed in origin, history of congenital craniofacial anomaly, major craniofacial trauma, orthodontic treatment, craniofacial reconstructive surgery and had crani ofacial deformities or irregular dentitions.

\section{Variables studied}

a. Variables studied through physical procedures ( Figure 1)
i. Mandible height (Stomion / sto - G nathion / gn)
ii. Mandible breadth (Gonion / go - Gonion / go)
iii. M outh width (Cheilion / ch - Cheilion / ch)

b. Variables studied through photographic procedures (Figure 1)
i. Upper lip height (Subnasale / sn - Stomion / sto)
ii. Lower lip height (Stomion / sto - Sublabiale / sl)
iii. Upper vermilion height (Labiale superius / Is - Stomion / sto)
iv. Lower vermilion height (Stomion / sto - Labiale inferius / li)
v. Philtrum length (Subnasale / sn - Labiale superius / Is)
vi. Philtrum width (Crista philtri / cph - Crista philtri / cph)

c. Calculated variables
i. Mandibular index (sto-gn / go-go x 100)
ii. Upper lip height to M outh width index (sn-sto / ch-ch $\times 100$ )
iii. Lower lip height to Upper lip height index (sto-sl / sn- sto x 100)
iv. Lower vermilion height to L ower lip height index (sto-li / sto-sl x 100)
v. Upper vermilion height to Philtrum length index (Is-sto / sn- $\mid \mathrm{s} \times 100)$
vi. Philtrum width to M outh width index (cph-cph / ch-ch $\times 100)$

\section{Procedures of measuring the variables studied}

To avoid accidental injury of the labial region, photographic procedure was used which had been shown a valid alternative of manual anthropometry provided that the images had been captured in a standardized fashion and the points chosen were easily identifiable $e^{4,6}$. B efore taking the physical measurements and frontal facial photograph, all facial jewelry was removed from the subject ${ }^{7}$ and was asked to maintain a neutral, relaxed facial expression with mouth closed naturally. Photographs were taken with a digital camera, at a 7.2 megapixel resolution, under the same lighting conditions using flash mode from a fixed distance of 4 feet using zoom function?. All the photographic measurements were taken in a computer program named adobe illustrator version-10.
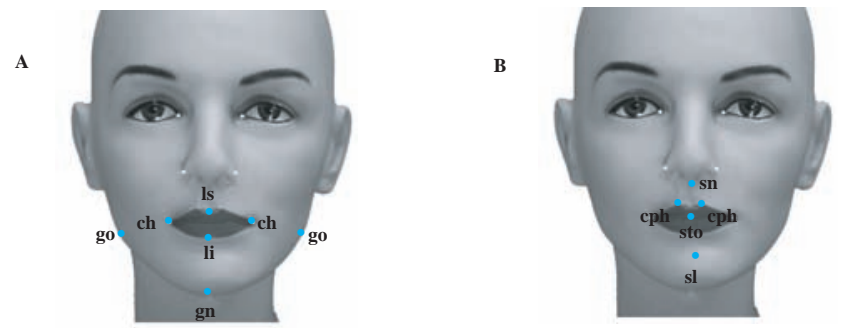

Figure 1: Diagrammatic representation of some important craniofacial anthropometric landmarks in frontal $(A, B)$ views of manikin

$$
\begin{array}{ll}
\text { gn }=\text { Gnathion } & s \mathrm{l}=\text { Sublabiale } \\
\text { go }=\text { Gonion } & \text { cph = Crista philtr } \\
\text { ch }=\text { Cheilion } & \text { sto }=\text { Stomion } \\
\text { Is }=\text { Labiale superius } & \text { sn = Subnasale } \\
\text { li }=\text { Labiale inferius } &
\end{array}
$$

The physical measurements and facial photographs were taken at a fixed time between $9 \mathrm{AM}$ and $5 \mathrm{PM}$ to eliminate the discrepancies due to diurnal variations $s^{8}$. All the measurements were taken twice to control for measurement error. The final value that was used for the study was the average of the two obtained values. A third reading was taken if the initial two measurements showed a major discrepancy and the two closer readings would then be used ${ }^{9,10}$.

\section{Data processing and analysis}

After collection of the data, their frequency distributions, central tendencies and dispersions were determined using SPSS version 12 . An independent " $\mathrm{t}$ " test was performed to evaluate if there was any significant difference in measurements between the two age groups setting a $p$ value of $<0.05$ as statistically significant.

\section{RESULTS}

Range, mean $\pm S D$ and $p$ value of the measurements are shown in Table 1 and 2. These tables also show statistically non significant difference between two age groups in all

\begin{tabular}{|c|c|c|c|c|}
\hline Variable & Age group (years) & Range (cm) & Mean $(\mathrm{cm}) \pm S D$ & p value* \\
\hline Mandible height & $\begin{array}{l}25-35 \\
35-45\end{array}$ & $\begin{array}{l}3.59-5.34 \\
3.63-5.36\end{array}$ & $\begin{array}{l}4.51 \pm 0.36 \\
4.41 \pm 0.43\end{array}$ & 0.25 (NS)t \\
\hline Mandible breadth & $\begin{array}{l}25-35 \\
35-45\end{array}$ & $\begin{array}{l}9.80-11.60 \\
9.80-11.40\end{array}$ & $\begin{array}{l}10.50 \pm 0.45 \\
10.59 \pm 0.42\end{array}$ & 0.35 (NS) \\
\hline Mouth width & $\begin{array}{l}25-35 \\
35-45\end{array}$ & $\begin{array}{l}3.88-5.29 \\
3.93-5.34\end{array}$ & $\begin{array}{l}4.57 \pm 0.31 \\
4.64 \pm 0.34\end{array}$ & 0.33 (NS) \\
\hline Upper lip height & $\begin{array}{l}25-35 \\
35-45\end{array}$ & $\begin{array}{l}1.59-2.69 \\
1.61-2.62\end{array}$ & $\begin{array}{l}1.96 \pm 0.19 \\
2.02 \pm 0.26\end{array}$ & 0.24 (NS) \\
\hline Lower lip height & $\begin{array}{l}25-35 \\
35-45\end{array}$ & $\begin{array}{l}1.05-1.95 \\
1.08-1.99\end{array}$ & $\begin{array}{l}1.46 \pm 0.19 \\
1.50 \pm 0.21\end{array}$ & 0.39 (NS) \\
\hline Upper vermilion height & $\begin{array}{l}25-35 \\
35-45\end{array}$ & $\begin{array}{l}0.47-1.05 \\
0.39-1.16\end{array}$ & $\begin{array}{l}0.76 \pm 0.12 \\
0.73 \pm 0.16\end{array}$ & 0.21 (NS) \\
\hline Lower vermilion height & $\begin{array}{l}25-35 \\
35-45\end{array}$ & $\begin{array}{l}0.65-1.41 \\
0.49-1.23\end{array}$ & $\begin{array}{l}0.99 \pm 0.16 \\
0.96 \pm 0.20\end{array}$ & 0.31 (NS) \\
\hline Philtrum length & $\begin{array}{l}25-35 \\
35-45\end{array}$ & $\begin{array}{l}0.69-1.76 \\
0.97-1.88\end{array}$ & $\begin{array}{l}1.21 \pm 0.21 \\
1.33 \pm 0.23\end{array}$ & $0.02(S)^{* *}$ \\
\hline Philtrum width & $\begin{array}{l}25-35 \\
35-45\end{array}$ & $\begin{array}{l}0.59-1.38 \\
0.74-1.46\end{array}$ & $\begin{array}{l}1.02 \pm 0.19 \\
1.03 \pm 0.16\end{array}$ & 0.85 (NS) \\
\hline
\end{tabular}
measurements except for philtrum length and upper vermilion height to philtrum length index.

Table 1: M easurements of lower jaw and orolabial region obtained through physical or photographic procedures 
Table 2: M easurements of calculated lower jaw and orolabial indices

\begin{tabular}{|c|c|c|c|c|}
\hline Craniofacial index & $\begin{array}{l}\text { Age group } \\
\text { (years) }\end{array}$ & Range (om) & Mean $(\mathrm{cm}) \pm S D$ & p valuek \\
\hline Mandibular index & $\begin{array}{l}25-35 \\
35-45\end{array}$ & $\begin{array}{l}33.28-54.50 \\
32.96-50.19\end{array}$ & $\begin{array}{l}43.02 \pm 4.18 \\
41.66 \pm 3.92\end{array}$ & $0.13(\mathrm{NS}) t$ \\
\hline $\begin{array}{l}\text { Upper lip height to } \\
\text { Mouth width index }\end{array}$ & $25-35$ & $33.33-57.58$ & $43.16 \pm 5.05$ & 0.68 (NS) \\
\hline \multirow{2}{*}{$\begin{array}{l}\text { Lower lip height to } \\
\text { Upper lip height index }\end{array}$} & $\begin{array}{l}35-45 \\
25-35\end{array}$ & $\begin{array}{l}35.42 \cdot 57.06 \\
45.72-93.64\end{array}$ & $\begin{array}{l}43.63 \pm 5.65 \\
74.97 \pm 10.50\end{array}$ & \multirow[t]{2}{*}{0.99 (NS) } \\
\hline & $35-45$ & $52.94-94.09$ & $74.95 \pm 11.02$ & \\
\hline \multirow{2}{*}{$\begin{array}{l}\text { Lower vermilion } \\
\text { height to Lower lip } \\
\text { height index }\end{array}$} & $25-35$ & $43.60-93.69$ & $68.44 \pm 10.21$ & \multirow[t]{2}{*}{0.09 (NS) } \\
\hline & $35-45$ & $28.00-87.79$ & $64.27 \pm 12.57$ & \\
\hline \multirow{2}{*}{$\begin{array}{l}\text { Upper vermilion } \\
\text { height to Philtrum } \\
\text { length index }\end{array}$} & $25-35$ & $30.72 \cdot 128.99$ & $65.85 \pm 20.12$ & \multirow[t]{2}{*}{$0.03(\mathrm{~S}) * *$} \\
\hline & $35-45$ & $26.35-103.57$ & $56.65 \pm 17.31$ & \\
\hline \multirow{2}{*}{$\begin{array}{l}\text { Philtrum width to } \\
\text { Mouth width index }\end{array}$} & $25-35$ & $12.64-32.60$ & $22.32 \pm 4.12$ & \multirow[t]{2}{*}{0.88 (NS) } \\
\hline & $35-45$ & $16.73 \cdot 34.89$ & $22.18 \pm 3.60$ & \\
\hline
\end{tabular}

$* p>0.05$, the result was considered as non-significant

$\dagger \mathrm{NS}=$ N on-significant

**S = Significant

\section{DISCUSSION}

When craniofacial anthropometry was introduced into clinical practice to quantify changes in the craniofacial framework, features distinguishing various races or ethnic groups were discovered ${ }^{3}$. So it is accepted that a single standard of facial aesthetics is not appropriate for application to diverse racial and ethnic groups ${ }^{11}$. Moreover, differences in craniofacial norms across different ages have also been documented. Therefore, there is a need to develop craniofacial norms for different age groups as well. This necessity rests on the fact that there will be greater validity if an individual is compared to referent data matched for their specific ethnic group and age. The participants included in this study were from southern part of $B$ angladesh (Chittagong and Rangamati cities).
In general, the present data were satisfactorily in concurrence with previous reports. For example, the mandible breadth of Chakma females was almost similar to Santhal ${ }^{12}, M$ anchu ${ }^{13}$, Evenks ${ }^{14}$, M ongol ${ }^{15}$, K orean $^{16}$ femal es.

Three-dimensional data collected by digital indirect anthropometry were reported by Sawyer et al ${ }^{17}$ for adult Caucasian and by Sforza et al. ${ }^{18}$ for white Italians. In comparison some values were larger some were smaller than the current ones. Such difference may be due to difference in technique. The present study use photographic indirect anthropometry while Sawyer et al. ${ }^{17}$ used stereophotogrammetry and Sforza et al. ${ }^{18}$ used computerized electromagnetic digitizer. B esides these, ethnicity of the sample was also different.

In a study Sforza et al. ${ }^{18}$ shows that the dimensions of the lips and orolabial region modify between young adulthood and adult up to eighth decade of life. But in this study except for philtrum length and upper vermilion height to philtrum length index such significant modification could not evaluate. The present study was a cross sectional in nature, so it may not represent the actual growth pattern of lips and orolabial region. However, only a few longitudinal studies showed age related significant modifications in lips and orolabial region.

\section{LIMITATIONS}

The subjects were selected from a convenient sample $\&$ also relatively small as compared to the total number of population. Besides this, it is a cross-sectional study. So, a longitudinal study on a larger sample is required to confirm the findings of this study.

\section{CONCLUSION}

The result of the present anthropometric study can be useful for anatomists and anthropologists to serve as a basic framework for estimating the standard of lower jaw and orolabial dimensions of this population and also to compare the craniofacial dimensions of other ethnic groups of Bangladesh with this ethnic group.

\section{ACKNOWLEDGEMENTS}

The author is extremely grateful to all the female subjects who have voluntarily participated and extended their kind cooperation during this laborious and time-consuming data collection. 


\section{REFERENCES}

1. Nagle E, Teibe U, Kapoka D. Craniofacial anthropometry in a group of healthy Latvian residents. A cta M edica Lituanica. 2005; 12(1):47-53.

2. Zankl A, M olinari L. A B ase-a tool for the rapid assessment of anthropometric measurements on handheld computers. A m. J. M ed. Genet. 2003; 121(A ):146-50.

3. Farkas LG, K atic M J, Forrest CR, A It KW, Bagic I, B altadjiev G, et al. International anthropometric study of facial morphology in various ethnic groups/races. J Craniofac Surg. 2005; 16(4):615-46.

4. Edler R, A garwal P, Wertheim D, G reenhill D. The use of anthropometric proportion indices in the measurement of facial attractiveness. Eur J Orthod. 2006; 28(3):274-81.

5. Sforza C, Ferrario V F. Three-dimensional analysis of facial morphology: growth, devel opment and aging of the orolabial region. Ital J A nat Embryol. 2010; 115(1/2):141-45.

6. Edler R, Rahim M A, Wertheim D, Greenhill D. The use of facial anthropometrics in aesthetic assessment. Cleft Palate Craniofac J. 2010; 47(1):48-57.

7. Simmons LW, R hodes $G$, Peters $M$, Koehler $N$. A re human preferences for facial symmetry focused on signals of developmental instability?. B ehav Ecol. 2004; 15(5):864-71.

8. Jadav HR, Shah GV. Determination of personal height from the length of head in Gujarat region. J A nat Soc India. 2004; 53(1):20-21.

9. N geow W C, A ljunid ST. Craniofacial anthropometric norms of M alaysian Indians. Indian J Dent Res. 2009; 20(3):313-39.

10. Starbuck JM, Ward RE. The affect of tissue depth variation on craniofacial reconstructions. Forensic Sci Int. 2007; 172:130-36.

11. J oy $O, A$ hmed $E$, Gabriel $O$, Ezon-ebidor $E$. A nthropometric study of the facial and nasal length of adult Igbo ethnic group in Nigeria. Internet J Biol A nthropol. 2009; 2(2).

12. Ghosh S, M alik SL. Sex differences in body size and shape among Santhals of West Bengal. A nthropol. 2007; 9(2):143-49.

13. Kubo H. A study on anthropometric measurement of head and face, and morphology of dental arch on $M$ anchu tribe. J K yushu Dent. Soc. 1997; 51(2):324-34.

14. Watanabe S. Physical anthropological study on the measurement of head and face, and morphology of dental arch on Evenks tribe, China. J Kyushu Dent. Soc. 2000; 54(5):469-82.

15. O kumura T. Physical anthropological study on the measurement of head and face, and morphology of dental arch of the M ongol tribe, China. J K yushu Dent. Soc. 1999; 53(1):1-12.

16. Kim H, Han DH, Roh Y M, Kim K, Park Y G. Facial anthropometric dimensions of Koreans and their associations with fit of quarter-mask respirators. Ind Health. 2003; 41:8-18.

17. Sawyer A R, M arlene S, N duka C. 3D Stereophotogrammetry Q uantitative Lip A nalysis. A esth Plast Surg. 2009;33:497-04.

18. Sforza C, Grandi G, Binelli M, Dolci C, M enezes M D, Ferrario VF. A ge- and sex-related changes in three-dimensional lip morphology. Forensic Sci Int. 2010; 200:182.e1-7. 